\title{
Study of Socio - Economic Profile of the Selected Pulses Growing Farmers in Mahabubnagar District of Telangana State
}

\author{
M. Vinaya Kumari*, Amit Kumar Masih, Nahar Singh, \\ Ashish Samarpit Noel and Kumud Shukla
}

Department of Agricultural Economics and Agribusiness Management, Sam Higginbottom

University of Agriculture, Technology and Sciences, Allahabad, Uttar Pradesh, 211007 India

*Corresponding author

\begin{tabular}{|l|}
\hline Ke y w o r d s \\
Socio-economic, \\
Pulses, Farmers, \\
Redgram, \\
Bengalgram, \\
Greengram, \\
Telangana, \\
Mahabubnagar \\
\hline Article Info \\
\hline $\begin{array}{l}\text { Accepted: } \\
\text { 24 June 2019 } \\
\text { Available Online: } \\
\text { 10 July } 2019\end{array}$ \\
\hline
\end{tabular}

\section{Keywords}

Socio-economic,

Pulses, Farmers,

Redgram,

Bengalgram,

Telangana

bubnagar

Accepted:

24 June 2019

10 July 2019

\section{A B S T R A C T}

The study was conducted to investigate the socio - economic profile of the selected pulses growing farmers in Mahabubnagar district of Telangana state. The state of Telangana was selected purposively for the study as the investigator hails from the state. Out of 31 districts of Telangana state, Mahabubnagar district was selected purposively for the study. In this district, the blocks recorded highest area was selected. In each block two villages with highest area under cultivation of particular crop were selected. The sample frame work incudes selection of three crops, three blocks and six villages purposively. From each selected village, 10 per cent respondents were selected randomly thus making a sample of 145 respondents for the study. The study shows that majority of the farmers belongs to middle age in red gram farm 53.35 per cent were as in bengalgram 53.29 per cent and green gram farm 55.97 per cent. the sample average percent of male and female for different farm group was 56.17 per cent and 44.00 per cent in redgram farms, were as in Bengal gram 56.59 per cent and 42.22 per cent and in greengram farm 53.80 and 45.62 per cent respectively. The study shows that majority of the farmers were literate 81.38 per cent in redgram, were as in bengalgram72.10 per cent and in green gram were 75.68 per cent respectively. Agriculture as a main occupation 66.66 per cent in redgram farms, were as 68.08 per cent in Bengal gram farms and 63.15 per cent green gram farms respectively. The majority of the farmers were medium farming experience, in redgram the sample average was 58.34 per cent were as in bengalgram farmers 65.78 per cent and in greengram farmers were 67.78 per cent. redgram farmers according to their annual income average sample size were high in medium income group 63.34 per cent in redgram, were as in bengalgram 61.76 per cent and in greengram crop 63.15 percent and good agriculture extension system was registered to enhance the efficiency of farm, the average size of the redgram farmers contact with extension agency was found to be 68.34 per cent in redgram were as in bengalgram65.95 per cent and in greengram farmers 68.42 per cent respectively. Vitamin B6, also called pyridoxine, is one of the B vitamins. It helps the body to convert food (carbohydrates) into fuel (glucose), which is used to produce energy. A simple and sensitive reversed-phase (RP) HPLC method was used for determination of vitamin B6 present in areca nut samples. Areca nut samples were collected from Shimoga, Davanagere, Chikkamagalur, Chitradurga, Dakshina Kannada and Udupi districts of Karnataka, India. RP- HPLC analysis was performed with UHPLC system (Thermo fisher-ultimate 3000) equipped with UV/Visible detector and $\mathrm{C}_{18}$ column. The column effluents were monitored at 220nm. Vitamin B6 in different district ranged from 10 to $91 \mathrm{ppm}$. The mean vitamin B6 content was lowest in Shimoga district $(15.68 \mathrm{ppm})$ and highest in Dakshina Kannada district (50.49 ppm). Vitamin $\mathrm{C}$ is a most important vitamin in the human diet, excessively present in fruits and vegetables. It is also known as ascorbic acid and is water-soluble. In areca nut vitamin $\mathrm{C}$ is present in trace amount. 


\section{Introduction}

Agriculture plays a vital role in India's economy. $54.6 \%$ of the population is engaged in agriculture and allied activities (census 2011) and it contributes $17.4 \%$ to the country's Gross Value Added for the year 2016-17 (at current prices). By giving significance, the Government of India implemented several schemes for the sustainable development in agriculture sector, the total geographical area of the country is $328.7 \mathrm{mh}$, out of which $140.1 \mathrm{mh}$ reported as net cultivated area and the gross cropped area is 198.4 million hectares with a cropping intensity of 142 percent, as per the land use statistics 214-15. The net area has sown works out to be 43 percent of the total geographical area. The net irrigated area is 68.4 million hectares. Agriculture and allied sectors contributed approximately 17.4 percent of India's GVA at current prices during 2016-17 (Annual Report 2017-18, www.agricoop.nic.in).

Pulses are an important commodity group of crops that provide high quality protein complementing cereal proteins for predominantly substantial vegetarian population of the country, although, India has been recorded as largest pulse crop cultivating in the World, in comparison the production of pulses in India is nearer to the total cereal crops productions, The cultivation of pulses builds-up a mechanism to fix atmospheric nitrogen in their root nodules and thus meet their nitrogen requirements to a great extent. In our country, pulses can be bring about with a minimum use of assets and it becomes a cheaper than animal protein, compare to other vegetables, pulses are less expensive, rich in protein content and can be cultivated as an mixed crop, sole crop and inter crop. Pulses needs less irrigation facility compare to cereals and mostly cultivated under rainfed conditions therefore, pulses are grown in areas after cereals/cash crops and give better returns. besides this pulses own some other standards such as they raise soil physical structure and soil fertility and rich in protein, suitable for mixed cropping, inter cropping, crop rotations and dry farming and supply green pods for vegetables and nutritious fodder for cattle as well (Annual Report DPD 2016-17).

\section{Socio- economic profile of sample farmers}

Socio- economic analysis is needed to have comprehensive idea on specific study area which may help the researcher to suggest better location specific feasible solutions for the improvement. Generally, the socioeconomic analysis focuses on identifying the adaptive capacity of individuals or communities based on their internal characteristics. The socio-economic characteristics of the respondents include educational status, age, family size, occupation, annual income, farming experience, category of the farmers as per the size of the holding.

\section{Materials and Methods}

\section{Description of the study area}

The study pertains to three major pulses namely Red gram, Bengal gram and Green gram in Mahabubnagar District of Telangana state, hence three crops were studied in three blocks namely, Redgram in Narva, Bengalgram in Utkoor, Greengram in Damaragidda as they were the major cultivating areas of those respective crops.

\section{Sampling Design}

The State of Telangana was selected purposively for the study as the investigator hails from the state. Out of 31 districts of Telangana state, Mahabubnagar district was 
selected purposively for the study. In this district, the blocks recorded highest area was selected. In each block two villages with highest area under cultivation of particular crop were selected. The sample frame work incudes selection of three crops, three blocks and six villages purposively. From each selected village, 10 per cent respondents were selected randomly thus making a sample of 145 respondents for the study. The data of the selected pulses farmers were obtained through personal interview method with the help of pre-tested interview schedule for the agricultural year 2017-18 based on farmer's recall.

\section{Tools of Analysis}

Descriptive/tabular analysis involving the computation of simple average and percentages were employed to present the data regarding the socio-economic profile of the respondents.

\section{Results and Discussion}

Detail description of Redgram sample size households/ farm families in different size of farms group

The composition of an average size of the Redgram farm families according to sex and age composition was indicated in table 1, average size of the farm families in small, medium and large size of farms groups were $5.43,5.54$ and 6.28 respectively. The sample average percentage of male and female for different size of farms groups was 56.17 per cent and 44.00 per cent respectively. It could also be seen from the table that age composition of different size of farms group. Highest sample average percentage of different size of farms belongs to the age composition of below 15-60 years $(53.35 \%)$ followed by below 15 years $(28.14 \%)$ and above 60 years and above (20.64\%) respectively. The probable reason for majority of the respondents being under middle age category might be due to the fact that most of the young people are not interested in farming and are looking for better livelihood options in urban area. Another reason may be middle aged are enthusiastic and have more work efficiency than the older or younger ones. The age of the farmer is expected to affect his labor productivity and output, These results are line with the findings of (Roy (2013), Abdulkadir (2015), Jamanal, S.K., and Sadaquath, S., 2017) and Uttam (2017).

\section{Detail description of Bengalgram sample size households/ farm families in differentsize of farms group}

The composition of an average size of the Bengalgram farm families according to sex and age composition was indicated in table 2 , average size of the farm families in small, medium and large size of farms groups were 5.52, 4.81 and 5.15 respectively. The sample average percentage of male and female for different size of farms groups was 56.59 per cent and 42.22 per cent respectively. It could also be seen from the table that age composition of different size of farms group. Highest sample average percentage of different size of farms belongs to the age composition of below 15-60 years $(53.29 \%)$ followed by below 15 years $(26.55 \%)$ and above 60 years and above (19.76\%) respectively. These results are line with the findings of (Roy, 2013; Abdulkadir, 2015; Jamanal and Sadaquath, 2017; Uttam, 2017).

\section{Detail description of Greengram sample size households/ farm families in different size of farms group}

The composition of an average size of the Greengram farm families according to sex and age composition was indicated in table 3 , average size of the farm families in small, 
medium and large size of farms groups were $5.11,4.95$ and 5.25 respectively. The sample average percentage of male and female for different size of farms groups was 53.80 per cent and 45.62 per cent respectively. It could also be seen from the table that age composition of different size of farms group. Highest sample average percentage of different size of farms belongs to the age composition of below 15-60 years (55.97\%) followed by below 15 years $(18.79 \%)$ and above 60 years and above (23.34\%) respectively. These results are line with the findings of (Roy, 2013; Abdulkadir, 2015; Jamanal and Sadaquath, 2017; Uttam, 2017).

\section{Detail description of Redgram literacy in different size of farm group}

Educational status of the farmers was one of the important criteria because it decides relative exposure of the farmers to new agricultural technology, interaction with traders, access to information and exports there by determining the decision making process of the farmer, Table 4, reveals that educational status of redgram farmers in different size of farms groups. Literacy percentage was highest in large size farms $(81.86 \%)$ followed by small size farms $(77.90$ $\%)$ and medium size farms (75.27 \%) respectively. This makes the sample average for different size of farms group was 81.38 per cent. Among small, medium and large size farms group literates were 24.78 per cent of farms had studied education up to intermediate, 1.24 per cent of farms then studied the primary education followed by 23.13per cent farms studied up to middle and high school. Only 13.23 per cent of farms had studied up to graduation. Therefore majority of the respondents in the study area is given is given importance to the minimum education. These finding are supported by the findings of Dhamodaran and Vasanth (2001) and Jamanal (2017).
From the table 4, it could be seen that illiteracy percentage was highest in medium size farms $(24.72 \%)$ followed by small size farms $(22.09 \%)$ and was lowest in large size farms $(18.15 \%)$ respectively. Sample average was 22.08 per cent for different size of farms groups.

\section{Detail description of Bengalgram literacy in different size of farm group}

Educational status of the farmers was one of the important criteria because it decides relative exposure of the farmers to new agricultural technology, interaction with traders, access to information and exports there by determining the decision making process of the farmer, Table 5 reveals that educational status of bengalgram farmers in different size of farms groups. Literacy percentage was highest in small size farms $(73.37 \%)$ followed by medium size farms $(72.97 \%)$ and large size farms $(68.54 \%)$ respectively. This makes the sample average for different size of farms group was 72.10 per cent. Among small, medium and large size farms group literates were 19.26 per cent of farms had studied education up to intermediate, 1.50 per cent of farms then studied the primary education followed by 21.19 per cent farms studied up to middle and high school. Only 16.55 per cent of farms had studied up to graduation. Therefore majority of the respondents in the study area is given is given importance to the minimum education. These finding are supported by the findings of Dhamodaran and Vasanth (2001) and Jamanal (2017).

From the table 5, it could be seen that illiteracy percentage was highest in large size farms $(31.46 \%)$ followed by medium size farms $(27.23 \%)$ and was lowest in small size farms $(26.81 \%)$ respectively. Sample average was 28.17 per cent for different size of farms groups. 


\section{Detail description of Greengram literacy in different size of farm group}

Educational status of the farmers was one of the important criteria because it decides relative exposure of the farmers to new agricultural technology, interaction with traders, access to information and exports there by determining the decision making process of the farmer, Table 6 , reveals that educational status of greengram farmers in different size of farms groups. Literacy percentage was highest in small size farms (77.92 \%) followed by medium size farms $(76.35 \%)$ and large size farms $(72.62 \%)$ respectively. This makes the sample average for different size of farms group was 75.68 per cent. Among small, medium and large size farms group literates were 19.64 per cent of farms had studied education up to intermediate, 21.02 per cent of farms then studied the primary education followed by 24.95 per cent farms studied up to middle and high school. Only 9.82 per cent of farms had studied up to graduation. Therefore majority of the respondents in the study area is given is given importance to the minimum education. These finding are supported by the findings of Dhamodaran and Vasanth (2001) and Jamanal (2017). From the table 6, it could be seen that illiteracy percentage was highest in large size farms $(27.38 \%)$ followed by small size farms $(22.08 \%)$ and was lowest in medium size farms $(21.18 \%)$ respectively. Sample average was 24.36 per cent for different size of farms groups.

\section{Detail description of Redgram occupational distribution in different size of farms group}

Table 7, revealed that size of the farms group in numbers for small, medium and large size of farms were 37, 13 and 10 respondents respectively. Primary occupation was highest in small size farms $(70.27 \%)$ followed by medium size farms $(61.53 \%)$ and lowest in case of large size farms $(60.00 \%)$ respectively. This makes the sample average for primary occupation was 66.66 per cent for different farms size groups. Secondary occupation for small, medium and large size of farms group was 18.92 per cent, 23.08 per cent and 20.00 per cent respectively and the sample average for secondary occupation was 20.00 per cent among different size of farms group. Tertiary occupation was highest in large size farms $(20.00 \%)$ followed by medium size farms $(15.38 \%)$ and lowest in small size farms $(10.82 \%)$ respectively. This makes the sample average for Territory occupation was 13.34 per cent in different size of farms groups. These findings are supported by the findings of Uttam (2017), Neethi (2014) and Samarpitha et al., (2016).

\section{Detail description of Bengalgram occupational distribution in different size of farms group}

Table 8, revealed that size of the farms group in numbers for small, medium and large size of farms were 24, 13 and 10 respondents respectively. Primary occupation was highest in small size farms $(75.00 \%)$ followed by medium size farms $(61.54 \%)$ and lowest in case of large size farms (60.00\%) respectively. This makes the sample average for primary occupation was 68.08 per cent for different farms size groups. Secondary occupation for small, medium and large size of farms group was 16.66 per cent, 23.08 per cent and 20.00 per cent respectively and the sample average for secondary occupation was 19.17 per cent among different size of farms group. Tertiary occupation was highest in large size farms $(20.00 \%)$ followed by medium size farms $(15.38 \%)$ and lowest in small size farms $(8.33 \%)$ respectively. This makes the sample average for Territory occupation was 12.76 per cent in different size of farms groups. These findings are supported 
by the findings of Uttam (2017), Neethi (2014) and Samarpitha et al., (2016).

Detail description of Greengram occupational distribution in different size of farms group

Table 9, revealed that size of the farms group in numbers for small, medium and large size of farms were 26, 8 and 4 respondents respectively. Primary occupation was highest in small size farms $(69.23 \%)$ followed by medium size farms $(50.00 \%)$ and in case of large size farms $(50.00 \%)$ respectively. This makes the sample average for primary occupation was 63.15 per cent for different farms size groups. Secondary occupation for small, medium and large size of farms group was 15.38 per cent, 37.50 per cent and 25.00 per cent respectively and the sample average for secondary occupation was 21.05 per cent among different size of farms group. Tertiary occupation was highest in large size farms $(25.00 \%)$ followed by small size farms (15.38 $\%)$ and lowest in medium size farms (12.50 $\%$ respectively. This makes the sample average for Territory occupation was 15.78 per cent in different size of farms groups. These findings are supported by the findings of Uttam (2017), Neethi (2014) and Samarpitha et al., (2016).

\section{Distribution of Redgram farmers according to their farming experience}

The number of years a farmer has spent in the farming business may give an indication of the practical knowledge he has acquired on how he can overcome certain inherent farm production and adoption problems, In order to have efficiency in crop management it is essential that farmers have experience in raising a particular crop

From the Table 10, it was found that more than half of farmers $(58.34 \%)$ had medium redgram growing experience (8-28 years), followed by more and less redgram growing experience i.e., 31.66 per cent ( $>28$ years) and 20.00 per cent $(<8$ years), respectively. The results were in conformity with that of Roy (2013), Yishak (2017), Neethi and Sailaja (2014).

Table.1 Detail description of Redgram sample size households/ farm families in different size of farms group

Number of Respondents $=60$

$\mathrm{SML}=37+13+10=60$

\begin{tabular}{|c|c|c|c|c|c|}
\hline \multirow[t]{2}{*}{ SI no } & \multirow[t]{2}{*}{ particulars } & \multicolumn{3}{|c|}{ Size of farm group } & \multirow[t]{2}{*}{ Sample average } \\
\hline & & Small & medium & large & \\
\hline 1 & $\begin{array}{l}\text { Average size of farm } \\
\text { families }\end{array}$ & $\begin{array}{l}5.43 \\
(100 \%)\end{array}$ & $\begin{array}{l}5.54 \\
(100 \%)\end{array}$ & $\begin{array}{l}6.28 \\
(100 \%)\end{array}$ & $\begin{array}{l}5.75 \\
(100)\end{array}$ \\
\hline \multirow[t]{2}{*}{2} & Male & $\begin{array}{l}2.89 \\
(53.22)\end{array}$ & $\begin{array}{l}3.30 \\
(59.56)\end{array}$ & $\begin{array}{l}3.50 \\
(55.73)\end{array}$ & $\begin{array}{l}3.23 \\
(56.17)\end{array}$ \\
\hline & Female & $\begin{array}{l}2.54 \\
(46.79)\end{array}$ & $\begin{array}{l}2.30 \\
(41.51)\end{array}$ & $\begin{array}{l}2.76 \\
(43.94)\end{array}$ & $\begin{array}{l}2.53 \\
(44.00)\end{array}$ \\
\hline \multirow[t]{4}{*}{3} & Age composition & & & & \\
\hline & Below 15 years & $\begin{array}{l}1.88 \\
(34.62)\end{array}$ & $\begin{array}{l}1.67 \\
(30.14)\end{array}$ & $\begin{array}{l}1.31 \\
(20.85)\end{array}$ & $\begin{array}{l}1.62 \\
(28.14)\end{array}$ \\
\hline & $15-60$ years & $\begin{array}{l}2.59 \\
(47.62)\end{array}$ & $\begin{array}{l}2.79 \\
(50.36)\end{array}$ & $\begin{array}{l}3.52 \\
(56.05)\end{array}$ & $\begin{array}{l}2.97 \\
(53.35)\end{array}$ \\
\hline & 60 years and above & $\begin{array}{l}0.94 \\
(17.37)\end{array}$ & $\begin{array}{l}1.08 \\
(19.49)\end{array}$ & $\begin{array}{l}1.45 \\
(23.08)\end{array}$ & $\begin{array}{l}1.15 \\
(20.64)\end{array}$ \\
\hline
\end{tabular}

Note: Figures in the parenthesis was indicating percentage to the total size of families 
Table.2 Detail description of Bengalgram sample size households/ farm families indifferent size of farms group

Number of Respondents $=47$

\begin{tabular}{|c|c|c|c|c|c|}
\hline \multirow{3}{*}{$\begin{array}{l}\text { Sl } \\
\text { no }\end{array}$} & \multirow{3}{*}{ particulars } & & & & $\mathrm{SML}=24+13+10=47$ \\
\hline & & \multicolumn{3}{|c|}{ Size of farm group } & \multirow{2}{*}{ Sample average } \\
\hline & & Small & medium & large & \\
\hline 1 & $\begin{array}{l}\text { Average size of farm } \\
\text { families }\end{array}$ & $\begin{array}{l}5.52 \\
(100 \%)\end{array}$ & $\begin{array}{l}4.81 \\
(100 \%)\end{array}$ & $\begin{array}{l}5.15 \\
(100 \%)\end{array}$ & $\begin{array}{l}5.16 \\
(100)\end{array}$ \\
\hline \multirow[t]{2}{*}{2} & Male & $\begin{array}{l}3.19 \\
(57.78)\end{array}$ & $\begin{array}{l}2.75 \\
(57.17)\end{array}$ & $\begin{array}{l}3 \\
(58.25)\end{array}$ & $\begin{array}{l}2.92 \\
(56.59)\end{array}$ \\
\hline & Female & $\begin{array}{l}2.33 \\
(42,21)\end{array}$ & $\begin{array}{l}2.06 \\
(42.82)\end{array}$ & $\begin{array}{l}2.15 \\
(41.74)\end{array}$ & $\begin{array}{l}2.18 \\
(42.22)\end{array}$ \\
\hline \multirow[t]{4}{*}{3} & Age composition & & & & \\
\hline & Below 15 years & $\begin{array}{l}1.19 \\
(21.55)\end{array}$ & $\begin{array}{l}1.38 \\
(28.69)\end{array}$ & $\begin{array}{l}1.62 \\
(31.45)\end{array}$ & $\begin{array}{l}1.37 \\
(26.55)\end{array}$ \\
\hline & $15-60$ years & $\begin{array}{l}3.24 \\
(58.69)\end{array}$ & $\begin{array}{l}2.56 \\
(53.22)\end{array}$ & $\begin{array}{l}2.46 \\
(51.14)\end{array}$ & $\begin{array}{l}2.75 \\
(53.29)\end{array}$ \\
\hline & 60 years and above & $\begin{array}{l}1.10 \\
(19.92)\end{array}$ & $\begin{array}{l}0.88 \\
(18.29)\end{array}$ & $\begin{array}{l}1.08 \\
(20.97)\end{array}$ & $\begin{array}{l}1.02 \\
(19.76)\end{array}$ \\
\hline
\end{tabular}

Note: Figures in the parenthesis was indicating percentage to the total size of families

Table.3 Detail description of Greengram sample size households/ farm families in different size of farms group

Number of respondents $=38$

$\mathrm{SML}=26+8+4=38$

\begin{tabular}{|c|c|c|c|c|c|}
\hline \multirow{2}{*}{$\begin{array}{l}\text { SI } \\
\text { no }\end{array}$} & \multirow[t]{2}{*}{ particulars } & \multicolumn{3}{|c|}{ Size of farm group } & \multirow[t]{2}{*}{ Sample average } \\
\hline & & Small & medium & large & \\
\hline 1 & $\begin{array}{l}\text { Average size of } \\
\text { farm families }\end{array}$ & $\begin{array}{l}5.11 \\
(100 \%)\end{array}$ & $\begin{array}{l}4.95 \\
(100 \%)\end{array}$ & $\begin{array}{l}5.25 \\
(100 \%)\end{array}$ & $\begin{array}{l}5.13 \\
(100.00)\end{array}$ \\
\hline \multirow[t]{2}{*}{2} & Male & $\begin{array}{l}2.66 \\
(52.08)\end{array}$ & $\begin{array}{l}2.85 \\
(57.64)\end{array}$ & $\begin{array}{l}2.78 \\
(52.98)\end{array}$ & $\begin{array}{l}2.76 \\
(53.80)\end{array}$ \\
\hline & Female & $\begin{array}{l}2.45 \\
(47.92)\end{array}$ & $\begin{array}{l}2.10 \\
(42.36)\end{array}$ & $\begin{array}{l}2.47 \\
(47.02)\end{array}$ & $\begin{array}{l}2.34 \\
(45.62)\end{array}$ \\
\hline \multirow[t]{4}{*}{3} & Age composition & & & & \\
\hline & Below 15 years & $\begin{array}{l}1.04 \\
(20.42)\end{array}$ & $\begin{array}{l}1.20 \\
(24.14)\end{array}$ & $\begin{array}{l}0.69 \\
(13.10)\end{array}$ & $\begin{array}{l}0.96 \\
(18.79)\end{array}$ \\
\hline & $15-60$ years & $\begin{array}{l}2.81 \\
(55)\end{array}$ & $\begin{array}{l}2.63 \\
(53.20)\end{array}$ & $\begin{array}{l}3.03 \\
(57.74)\end{array}$ & $\begin{array}{l}2.82 \\
(55.97)\end{array}$ \\
\hline & 60 years and above & $\begin{array}{l}1.26 \\
(24.58)\end{array}$ & $\begin{array}{l}1.12 \\
(22.66)\end{array}$ & $\begin{array}{l}1.53 \\
(29.17)\end{array}$ & $\begin{array}{l}1.30 \\
(23.34)\end{array}$ \\
\hline
\end{tabular}

Note: Figures in the parenthesis was indicating percentage to the total size of families 
Table.4 Detail description of Redgram literacy in different size of farm group

Number of Respondents $=60$

$\mathrm{SML}=37+13+10=60$

\begin{tabular}{|c|c|c|c|c|c|}
\hline \multirow{2}{*}{$\begin{array}{l}\text { SI } \\
\text { no } \\
\end{array}$} & \multirow[t]{2}{*}{ particulars } & \multicolumn{3}{|c|}{ Size of farm group } & \multirow[t]{2}{*}{ Sample average } \\
\hline & & Small & medium & large & \\
\hline 1 & $\begin{array}{l}\text { Average size of farm } \\
\text { families }\end{array}$ & $\begin{array}{l}5.43 \\
(100 \%)\end{array}$ & $\begin{array}{l}5.54 \\
(100 \%)\end{array}$ & $\begin{array}{l}6.28 \\
(100 \%)\end{array}$ & \begin{tabular}{|l|}
5.75 \\
$(100.00)$
\end{tabular} \\
\hline 2 & \multicolumn{5}{|l|}{ Educational status } \\
\hline i & Primary & \begin{tabular}{|l|}
1.07 \\
$(17.04)$
\end{tabular} & $\begin{array}{l}0.83 \\
(14.98)\end{array}$ & \begin{tabular}{|l|}
1.27 \\
$(17.04)$
\end{tabular} & \begin{tabular}{|l|}
0.07 \\
$(1.24)$
\end{tabular} \\
\hline ii & Middle high school & $\begin{array}{l}1.40 \\
(22.45)\end{array}$ & $\begin{array}{l}1.17 \\
(21.12)\end{array}$ & $\begin{array}{l}1.42 \\
(22.45)\end{array}$ & $\begin{array}{l}1.33 \\
(23.13)\end{array}$ \\
\hline iii & intermediate & $\begin{array}{l}1.30 \\
(25.32)\end{array}$ & $\begin{array}{l}1.25 \\
(22.56)\end{array}$ & $\begin{array}{l}1.59 \\
(25.32)\end{array}$ & $\begin{array}{l}1.38 \\
(24.78)\end{array}$ \\
\hline iv & $\begin{array}{l}\text { Graduation and } \\
\text { above }\end{array}$ & $\begin{array}{l}0.46 \\
(13.69)\end{array}$ & $\begin{array}{l}0.92 \\
(16.61)\end{array}$ & $\begin{array}{l}0.86 \\
(13.69)\end{array}$ & $\begin{array}{l}0.76 \\
(13.23)\end{array}$ \\
\hline 3 & Total literacy & $\begin{array}{l}4.23 \\
(77.90)\end{array}$ & $\begin{array}{l}4.17 \\
(75.27)\end{array}$ & $\begin{array}{l}5.14 \\
(81.86)\end{array}$ & $\begin{array}{l}4.53 \\
(81.38)\end{array}$ \\
\hline 4 & Total illiteracy & $\begin{array}{l}1.20 \\
(22.09)\end{array}$ & $\begin{array}{l}1.37 \\
(24.72)\end{array}$ & $\begin{array}{l}1.14 \\
(18.15)\end{array}$ & $\begin{array}{l}1.27 \\
(22.08)\end{array}$ \\
\hline
\end{tabular}

Note: Figures in the parenthesis was indicating percentage to the total size of families

Table.5 Detail description of Bengalgram literacy in different size of farm group

Number of respondents $=47$

$\mathrm{SML}=24+13+10=47$

\begin{tabular}{|c|c|c|c|c|c|}
\hline \multirow{2}{*}{$\begin{array}{l}\text { SI } \\
\text { no }\end{array}$} & \multirow[t]{2}{*}{ Particulars } & \multicolumn{3}{|c|}{ Size of farm group } & \multirow[t]{2}{*}{ Sample average } \\
\hline & & Small & medium & large & \\
\hline 1 & $\begin{array}{l}\text { Average size of farm } \\
\text { families }\end{array}$ & $\begin{array}{l}5.52 \\
(100 \%)\end{array}$ & $\begin{array}{l}4.81 \\
(100 \%)\end{array}$ & $\begin{array}{l}5.15 \\
(100 \%)\end{array}$ & $\begin{array}{l}5.19 \\
(100.00)\end{array}$ \\
\hline 2 & \multicolumn{5}{|l|}{ Educational status } \\
\hline i & Primary & $\begin{array}{l}0.95 \\
(17.21)\end{array}$ & $\begin{array}{l}0.63 \\
(13.10)\end{array}$ & $\begin{array}{l}0.69 \\
(13.40)\end{array}$ & $\begin{array}{l}0.78 \\
(1.50)\end{array}$ \\
\hline ii & Middle high school & $\begin{array}{l}1.24 \\
(22.46)\end{array}$ & $\begin{array}{l}1.06 \\
(22.04)\end{array}$ & $\begin{array}{l}0.92 \\
(17.86)\end{array}$ & $\begin{array}{l}1.10 \\
(21.19)\end{array}$ \\
\hline iii & intermediate & $\begin{array}{l}0.86 \\
(15.58)\end{array}$ & $\begin{array}{l}1.19 \\
(24.74)\end{array}$ & $\begin{array}{l}1.00 \\
(19.42)\end{array}$ & $\begin{array}{l}1.00 \\
(19.26)\end{array}$ \\
\hline iv & $\begin{array}{l}\text { Graduation and } \\
\text { above }\end{array}$ & $\begin{array}{l}1 \\
(18.12)\end{array}$ & $\begin{array}{l}0.63 \\
(13.10)\end{array}$ & $\begin{array}{l}0.92 \\
(17.86)\end{array}$ & $\begin{array}{l}0.86 \\
(16.55)\end{array}$ \\
\hline 3 & Total literacy & $\begin{array}{l}4.05 \\
(73.37)\end{array}$ & $\begin{array}{l}3.51 \\
(72.97)\end{array}$ & $\begin{array}{l}3.53 \\
(68.54)\end{array}$ & $\begin{array}{l}3.67 \\
(72.10)\end{array}$ \\
\hline 4 & Total illiteracy & $\begin{array}{l}1.47 \\
(26.81)\end{array}$ & $\begin{array}{l}1.30 \\
(27.23)\end{array}$ & $\begin{array}{l}1.98 \\
(31.46)\end{array}$ & $\begin{array}{l}1.58 \\
(28.17)\end{array}$ \\
\hline
\end{tabular}

Note: Figures in the parenthesis was indicating percentage to the total size of families 
Table.6 Detail description of Greengram literacy in different size of farm group

Number of respondents $=38$

$\mathrm{SML}=26+8+4=38$

\begin{tabular}{|l|l|l|l|l|l|}
\hline SI no & Particulars & Size of farm group & \multicolumn{2}{l|}{ Sample average } \\
\cline { 3 - 6 } & & Small & medium & large & \\
\hline $\mathbf{1}$ & Average size of farm & 5.11 & 4.95 & 5.25 & \\
& families & $(100 \%)$ & $(100 \%)$ & $(100 \%)$ & 5.09 \\
& Educational status & 1.04 & 1.05 & 1.13 & $(100.00)$ \\
\hline $\mathbf{2}$ & Primary & $(20.42)$ & $(21.18)$ & $(21.43)$ & $(21.02)$ \\
\hline $\mathbf{i}$ & & 1.47 & 1.27 & 1.09 & 1.27 \\
\hline ii & Middle high school & $(28.75)$ & $(25.62)$ & $(20.83)$ & $(24.95)$ \\
\hline iii & intermediate & 1.00 & 0.95 & 1.06 & 1.00 \\
& & $(19.58)$ & $(19.21)$ & $(20.24)$ & $(19.64)$ \\
\hline iv & Graduation and above & 0.47 & 0.51 & 0.53 & 0.50 \\
\hline & & $(9.17)$ & $(10.34)$ & $(10.12)$ & $(9.82)$ \\
\hline $\mathbf{3}$ & Total literacy & 3.98 & 3.78 & 3.81 & 3.85 \\
& & $(77.92)$ & $(76.35)$ & $(72.62)$ & $(75.68)$ \\
\hline $\mathbf{4}$ & Total illiteracy & 1.13 & 1.17 & 1.44 & 1.24 \\
\hline
\end{tabular}

Note: Figures in the parenthesis was indicating percentage to the total size of families

Table.7 Detail description of Redgram occupational distribution in different size of farms group

Number of Respondents $=60$

$\mathrm{SML}=37+13+10=60$

\begin{tabular}{|c|c|c|c|c|c|}
\hline \multirow{2}{*}{$\begin{array}{l}\text { Sl. } \\
\text { No }\end{array}$} & \multirow[t]{2}{*}{ particulars } & \multicolumn{4}{|c|}{ Size of farm groups } \\
\hline & & small & medium & large & Total number of samples \\
\hline 1 & $\begin{array}{l}\text { Size of farm groups } \\
\text { (in numbers) }\end{array}$ & $\begin{array}{l}37 \\
(100)\end{array}$ & $\begin{array}{l}13 \\
(100)\end{array}$ & $\begin{array}{l}10 \\
(100)\end{array}$ & $\begin{array}{l}60 \\
(100)\end{array}$ \\
\hline i & $\begin{array}{l}\text { One occupation } \\
\text { (primary occupation) }\end{array}$ & $\begin{array}{l}26 \\
(70.27)\end{array}$ & $\begin{array}{l}8 \\
(61.53)\end{array}$ & $\begin{array}{l}6 \\
(60.00)\end{array}$ & $\begin{array}{l}40 \\
(66.66)\end{array}$ \\
\hline ii & $\begin{array}{l}\text { Two occupation } \\
\text { (secondary occupation) }\end{array}$ & $\begin{array}{l}7 \\
(18.92)\end{array}$ & $\begin{array}{l}3 \\
(23.08)\end{array}$ & $\begin{array}{l}2 \\
(20.00)\end{array}$ & $\begin{array}{l}12 \\
(20.00)\end{array}$ \\
\hline iii & $\begin{array}{l}\text { Three occupation } \\
\text { (tertiary occupation) }\end{array}$ & $\begin{array}{l}4 \\
(10.82)\end{array}$ & $\begin{array}{l}2 \\
(15.38)\end{array}$ & $\begin{array}{l}2 \\
(20.00)\end{array}$ & $\begin{array}{l}8 \\
(13.34)\end{array}$ \\
\hline
\end{tabular}

Note: Figures in the parenthesis indicates percentage to the total size of farms group

Table.8 Detail description of Bengalgram occupational distribution in different size of farms group

Number of respondents $=47$

$\mathrm{SML}=24+13+10=47$

\begin{tabular}{|l|l|l|l|l|l|}
\hline Sl. & particulars & \multicolumn{3}{c|}{ Size of farm groups } \\
\cline { 3 - 6 } No & & small & medium & large & Total number of samples \\
\hline $\mathbf{1}$ & Size of farm groups & 24 & 13 & 10 & 47 \\
& (in numbers) & $(100)$ & $(100)$ & $(100)$ & $(100)$ \\
\hline $\mathbf{i}$ & $\begin{array}{l}\text { One occupation } \\
\text { (primary occupation) }\end{array}$ & 18 & 8 & 6 & 32 \\
& $(75.00)$ & $(61.54)$ & $(60.00)$ & $(68.08)$ \\
\hline ii & $\begin{array}{l}\text { Two occupation } \\
\text { (secondary occupation) }\end{array}$ & 4 & 3 & 2 & 9 \\
& $(16.66)$ & $(23.08)$ & $(20.00)$ & $(19.17)$ \\
\hline iii & $\begin{array}{l}\text { Three occupation } \\
\text { (tertiary occupation) }\end{array}$ & 2 & 2 & 2 & 6 \\
& $(8.33)$ & $(15.38)$ & $(20.00)$ & $(12.76)$ \\
\hline
\end{tabular}

Note: Figures in the parenthesis indicates percentage to the total size of farms group 
Table.9 Detail description of Greengram occupational distribution in different size of farms group

Number of respondents $=38$

$\mathrm{SML}=26+8+4=38$

\begin{tabular}{|c|c|c|c|c|c|}
\hline \multirow{2}{*}{$\begin{array}{l}\text { Sl. } \\
\text { No }\end{array}$} & \multirow[t]{2}{*}{ particulars } & \multicolumn{4}{|c|}{ Size of farm groups } \\
\hline & & small & medium & large & Total number of samples \\
\hline 1 & $\begin{array}{l}\text { Size of farm groups } \\
\text { (in numbers) }\end{array}$ & $\begin{array}{l}26 \\
(100)\end{array}$ & $\begin{array}{l}8 \\
(100)\end{array}$ & $\begin{array}{l}4 \\
(100)\end{array}$ & $\begin{array}{l}38 \\
(100)\end{array}$ \\
\hline i & $\begin{array}{l}\text { One occupation } \\
\text { (primary occupation) }\end{array}$ & $\begin{array}{l}18 \\
(69.23)\end{array}$ & $\begin{array}{l}4 \\
(50.00)\end{array}$ & $\begin{array}{l}2 \\
(50.00)\end{array}$ & $\begin{array}{l}24 \\
(63.15)\end{array}$ \\
\hline ii & $\begin{array}{l}\text { Two occupation } \\
\text { (secondary occupation) }\end{array}$ & $\begin{array}{l}4 \\
(15.38)\end{array}$ & $\begin{array}{l}3 \\
(37.50)\end{array}$ & $\begin{array}{l}1 \\
(25.00)\end{array}$ & $\begin{array}{l}8 \\
(21.05)\end{array}$ \\
\hline iii & $\begin{array}{l}\text { Three occupation } \\
\text { (tertiary occupation) }\end{array}$ & $\begin{array}{l}4 \\
(15.38)\end{array}$ & $\begin{array}{l}1 \\
(12.50)\end{array}$ & $\begin{array}{l}1 \\
(25.00)\end{array}$ & $\begin{array}{l}6 \\
(15.78)\end{array}$ \\
\hline
\end{tabular}

Note: Figures in the parenthesis indicates percentage to the total size of farms group

Table.10 Distribution of Redgram farmers according to their farming experience

Number of Respondents $=60$

$\mathrm{SML}=37+13+10=60$

\begin{tabular}{|c|c|c|c|c|c|}
\hline \multirow{2}{*}{$\begin{array}{l}\text { SI. } \\
\text { No. }\end{array}$} & \multirow[t]{2}{*}{ Particulars } & \multicolumn{3}{|c|}{ Size of farm groups } & \multirow{2}{*}{$\begin{array}{l}\text { Total number } \\
\text { of samples }\end{array}$} \\
\hline & & small & medium & large & \\
\hline & $\begin{array}{l}\text { Size of farm groups } \\
\text { (in numbers) }\end{array}$ & $\begin{array}{l}37 \\
(100)\end{array}$ & $\begin{array}{l}13 \\
(100)\end{array}$ & $\begin{array}{l}10 \\
(100)\end{array}$ & $\begin{array}{l}60 \\
(100)\end{array}$ \\
\hline 1. & Low (<8 years) & $\begin{array}{l}8 \\
(21.62)\end{array}$ & $\begin{array}{l}2 \\
(15.38)\end{array}$ & $\begin{array}{l}2 \\
(20.00)\end{array}$ & $\begin{array}{l}12 \\
(20.00)\end{array}$ \\
\hline 2. & Medium (8-28 years) & $\begin{array}{l}20 \\
(54.05)\end{array}$ & $\begin{array}{l}9 \\
(69.23)\end{array}$ & $\begin{array}{l}6 \\
(60.00)\end{array}$ & $\begin{array}{l}35 \\
(58.34)\end{array}$ \\
\hline 3. & High (>28 years) & $\begin{array}{l}9 \\
(24.32)\end{array}$ & $\begin{array}{l}2 \\
(15.38)\end{array}$ & $\begin{array}{l}2 \\
(20.00)\end{array}$ & $\begin{array}{l}13 \\
(31.66)\end{array}$ \\
\hline
\end{tabular}

Note: Figures in the parenthesis indicates percentage to the total size of farms group

Table.11 Distribution of Bengalgram farmers according to their farming experience

Number of Respondents $=47$

$\mathrm{SML}=24+13+10=47$

\begin{tabular}{|c|c|c|c|c|c|}
\hline \multirow{2}{*}{$\begin{array}{l}\text { SI. } \\
\text { No. }\end{array}$} & \multirow[t]{2}{*}{ particulars } & \multicolumn{3}{|c|}{ Size of farm groups } & \multirow{2}{*}{$\begin{array}{l}\text { Total number } \\
\text { of samples }\end{array}$} \\
\hline & & small & medium & large & \\
\hline & $\begin{array}{l}\text { Size of farm groups } \\
\text { (in numbers) }\end{array}$ & $\begin{array}{l}24 \\
(100)\end{array}$ & $\begin{array}{l}13 \\
(100)\end{array}$ & $\begin{array}{l}10 \\
(100)\end{array}$ & $\begin{array}{l}47 \\
(100)\end{array}$ \\
\hline 1. & Low ( $<8$ years $)$ & $\begin{array}{l}4 \\
(16.66)\end{array}$ & $\begin{array}{l}3 \\
(0.23)\end{array}$ & $\begin{array}{l}2 \\
(20.00)\end{array}$ & $\begin{array}{l}9 \\
(19.17)\end{array}$ \\
\hline 2. & Medium (8-28 years) & $\begin{array}{l}14 \\
(58.34)\end{array}$ & $\begin{array}{l}8 \\
(61.54)\end{array}$ & $\begin{array}{l}5 \\
(50.00)\end{array}$ & $\begin{array}{l}27 \\
(57.44)\end{array}$ \\
\hline 3. & High (>28 years) & $\begin{array}{l}6 \\
(25.00)\end{array}$ & $\begin{array}{l}2 \\
(15.38)\end{array}$ & $\begin{array}{l}3 \\
(30.00)\end{array}$ & $\begin{array}{l}11 \\
(23.42)\end{array}$ \\
\hline
\end{tabular}

Note: Figures in the parenthesis indicates percentage to the total size of farms group 
Table.12 Distribution of Greengram farmers according to their farming experience

Number of respondents $=38$

$\mathrm{SML}=26+8+4=38$

\begin{tabular}{|c|c|c|c|c|c|}
\hline \multirow{2}{*}{$\begin{array}{l}\text { SI. } \\
\text { No. }\end{array}$} & \multirow[t]{2}{*}{ particulars } & \multicolumn{3}{|c|}{ Size of farm groups } & \multirow{2}{*}{$\begin{array}{l}\text { Total number } \\
\text { of samples }\end{array}$} \\
\hline & & small & medium & large & \\
\hline & $\begin{array}{l}\text { Size of farm groups } \\
\text { (in numbers) }\end{array}$ & $\begin{array}{l}26 \\
(100)\end{array}$ & $\begin{array}{l}8 \\
(100)\end{array}$ & $\begin{array}{l}4 \\
(100)\end{array}$ & $\begin{array}{l}38 \\
(100)\end{array}$ \\
\hline 1. & Low (<8 years) & $\begin{array}{l}4 \\
(15.38)\end{array}$ & $\begin{array}{l}1 \\
(12.50)\end{array}$ & $\begin{array}{l}1 \\
(25.00)\end{array}$ & $\begin{array}{l}6 \\
(15.78)\end{array}$ \\
\hline 2. & Medium (8-28 years) & $\begin{array}{l}18 \\
(69.23)\end{array}$ & $\begin{array}{l}5 \\
(62.50)\end{array}$ & $\begin{array}{l}2 \\
(50.00)\end{array}$ & $\begin{array}{l}25 \\
(65.78)\end{array}$ \\
\hline 3. & High (>28 years) & $\begin{array}{l}4 \\
(15.38)\end{array}$ & $\begin{array}{l}2 \\
(25.00)\end{array}$ & $\begin{array}{l}1 \\
(25.00)\end{array}$ & $\begin{array}{l}7 \\
(18.42)\end{array}$ \\
\hline
\end{tabular}

Note: Figures in the parenthesis indicates percentage to the total size of farms group

Table.13 Distribution of Redgram farmers according to their annual Income

Number of respondents $=60$

$\mathrm{SML}=37+13+10=60$

\begin{tabular}{|c|c|c|c|c|c|}
\hline \multirow{2}{*}{$\begin{array}{l}\text { SI. } \\
\text { No. }\end{array}$} & \multirow[t]{2}{*}{ Characteristics } & \multicolumn{3}{|c|}{ Size of farm group } & \multirow{2}{*}{$\begin{array}{l}\text { Total number } \\
\text { of samples }\end{array}$} \\
\hline & & small & medium & large & \\
\hline & $\begin{array}{l}\text { Size of farm groups } \\
\text { (in numbers) }\end{array}$ & $\begin{array}{l}37 \\
(100)\end{array}$ & $\begin{array}{l}13 \\
(100)\end{array}$ & $\begin{array}{l}10 \\
(100)\end{array}$ & $\begin{array}{l}60 \\
(100)\end{array}$ \\
\hline 1. & Lower income group $(<$ Rs.302593/-) & $\begin{array}{l}8 \\
(21.62)\end{array}$ & $\begin{array}{l}3 \\
(23.08)\end{array}$ & $\begin{array}{l}2 \\
(20.00)\end{array}$ & $\begin{array}{l}13 \\
(21.66)\end{array}$ \\
\hline 2. & Middle income group (Rs.302593-1420354/-) & $\begin{array}{l}24 \\
(64.86)\end{array}$ & $\begin{array}{l}8 \\
(61.54)\end{array}$ & $\begin{array}{l}6 \\
(60.00)\end{array}$ & $\begin{array}{l}38 \\
(63.34)\end{array}$ \\
\hline 3. & Higher income group (>Rs.1420354/-) & $\begin{array}{l}5 \\
(13.52)\end{array}$ & $\begin{array}{l}2 \\
(15.38)\end{array}$ & $\begin{array}{l}2 \\
(20.00)\end{array}$ & $\begin{array}{l}9 \\
(15.00)\end{array}$ \\
\hline
\end{tabular}

Note: Figures in the parenthesis indicates percentage to the total size of farms group

Table.14 Distribution of Bengalgram farmers according to their annual Income

Number of respondents $=47$

\begin{tabular}{|c|c|c|c|c|c|}
\hline \multirow{2}{*}{$\begin{array}{l}\text { SI. } \\
\text { No. }\end{array}$} & \multirow[t]{2}{*}{ Characteristics } & \multicolumn{3}{|c|}{ Size of farm group } & \multirow{2}{*}{$\begin{array}{l}\text { Total number } \\
\text { of samples }\end{array}$} \\
\hline & & small & medium & large & \\
\hline & $\begin{array}{l}\text { Size of farm groups } \\
\text { (in numbers) }\end{array}$ & $\begin{array}{l}24 \\
(100)\end{array}$ & $\begin{array}{l}13 \\
(100)\end{array}$ & $\begin{array}{l}10 \\
(100)\end{array}$ & $\begin{array}{l}47 \\
(100)\end{array}$ \\
\hline 1. & Lower income group (<Rs.302593/-) & $\begin{array}{l}5 \\
(20.84)\end{array}$ & $\begin{array}{l}3 \\
(23.08)\end{array}$ & $\begin{array}{l}2 \\
(20.00)\end{array}$ & $\begin{array}{l}10 \\
(21.27)\end{array}$ \\
\hline 2. & Middle income group (Rs.302593-1420354/-) & $\begin{array}{l}15 \\
(62.50)\end{array}$ & $\begin{array}{l}8 \\
(61.51)\end{array}$ & $\begin{array}{l}6 \\
(60.00)\end{array}$ & $\begin{array}{l}29 \\
(61.76)\end{array}$ \\
\hline 3. & Higher income group (>Rs.1420354/-) & $\begin{array}{l}4 \\
(16.66)\end{array}$ & $\begin{array}{l}2 \\
(15.38)\end{array}$ & $\begin{array}{l}2 \\
(20.00)\end{array}$ & $\begin{array}{l}8 \\
(17.06)\end{array}$ \\
\hline
\end{tabular}

Note: Figures in the parenthesis indicates percentage to the total size of farms group 
Table.15 Distribution of Greengram farmers according to their annual Income

Number of respondents $=38$

$\mathrm{SML}=26+8+4=38$

\begin{tabular}{|c|c|c|c|c|c|}
\hline \multirow{2}{*}{$\begin{array}{l}\text { SI. } \\
\text { No. }\end{array}$} & \multirow[t]{2}{*}{ Characteristics } & \multicolumn{3}{|c|}{ Size of farm group } & \multirow{2}{*}{$\begin{array}{l}\text { Total } \\
\text { number } \\
\text { of } \\
\text { samples }\end{array}$} \\
\hline & & small & medium & large & \\
\hline & $\begin{array}{l}\text { Size of farm groups } \\
\text { (in numbers) }\end{array}$ & $\begin{array}{l}26 \\
(100)\end{array}$ & $\begin{array}{l}8 \\
(100)\end{array}$ & $\begin{array}{l}4 \\
(100)\end{array}$ & $\begin{array}{l}38 \\
(100)\end{array}$ \\
\hline 1. & Lower income group (<Rs.302593/-) & $\begin{array}{l}5 \\
(19.24)\end{array}$ & $\begin{array}{l}2 \\
(25.00)\end{array}$ & $\begin{array}{l}1 \\
(25.00)\end{array}$ & $\begin{array}{l}8 \\
(21.08)\end{array}$ \\
\hline 2. & Middle income group (Rs.302593-1420354/-) & $\begin{array}{l}17 \\
(65.38)\end{array}$ & $\begin{array}{l}5 \\
(62.50)\end{array}$ & $\begin{array}{l}2 \\
(50.00)\end{array}$ & $\begin{array}{l}24 \\
(63.15)\end{array}$ \\
\hline 3. & Higher income group (>Rs.1420354/-) & $\begin{array}{l}4 \\
(15.38)\end{array}$ & $\begin{array}{l}1 \\
(12.50)\end{array}$ & $\begin{array}{l}1 \\
(25.00)\end{array}$ & $\begin{array}{l}6 \\
(15.78)\end{array}$ \\
\hline
\end{tabular}

Note: Figures in the parenthesis indicates percentage to the total size of farms group

Table.16 Contact with Extension Agency

Number of respondents $=60$

$\mathrm{SML}=37+13+10=60$

\begin{tabular}{|c|c|c|c|c|c|}
\hline \multirow{2}{*}{$\begin{array}{l}\text { SI. } \\
\text { No. }\end{array}$} & \multirow[t]{2}{*}{ Characteristics } & \multicolumn{3}{|c|}{ Size of farm group } & \multirow{2}{*}{$\begin{array}{l}\text { Total } \\
\text { number of } \\
\text { samples }\end{array}$} \\
\hline & & small & medium & large & \\
\hline & $\begin{array}{l}\text { Size of farm groups } \\
\text { (in numbers) }\end{array}$ & $\begin{array}{l}37 \\
(100)\end{array}$ & $\begin{array}{l}13 \\
(100)\end{array}$ & $\begin{array}{l}10 \\
(100)\end{array}$ & $\begin{array}{l}60 \\
(100)\end{array}$ \\
\hline 1. & Maintain contact & $\begin{array}{l}27 \\
(45.94)\end{array}$ & $\begin{array}{l}7 \\
(53.84)\end{array}$ & $\begin{array}{l}7 \\
(70.00)\end{array}$ & $\begin{array}{l}41 \\
(68.34)\end{array}$ \\
\hline 2. & Do not maintain contact & $\begin{array}{l}10 \\
(27.02)\end{array}$ & $\begin{array}{l}6 \\
(46.15)\end{array}$ & $\begin{array}{l}3 \\
(30.00)\end{array}$ & $\begin{array}{l}19 \\
(31.66)\end{array}$ \\
\hline
\end{tabular}

Note: Figures in the parenthesis indicates percentage to the total size of farms group

Table.17 Contact with extension agency

Number of respondents $=47$

$\mathrm{SML}=24+13+10=47$

\begin{tabular}{|l|l|l|l|l|l|}
\hline SI. & Characteristics & \multicolumn{3}{|l|}{ Size of farm group } & $\begin{array}{l}\text { Total } \\
\text { No. }\end{array}$ \\
\cline { 3 - 6 } & & small & medium & large & samples \\
\hline & $\begin{array}{l}\text { Size of farm groups } \\
\text { (in numbers) }\end{array}$ & 24 & 13 & 10 & 47 \\
\hline 1. & Maintain contact & $(100)$ & $(100)$ & $(100)$ & $(100)$ \\
\hline 2. & Do not maintain contact & 17 & 8 & 6 & 31 \\
& & $(70.84)$ & $(61.53)$ & $(60.00)$ & $(65.95)$ \\
\hline
\end{tabular}

Note: Figures in the parenthesis indicates percentage to the total size of farms group 
Table.18 Contact with extension agency

Number of respondents $=38$

$\mathrm{SML}=26+8+4=38$

\begin{tabular}{|c|c|c|c|c|c|}
\hline \multirow{2}{*}{$\begin{array}{l}\text { SI. } \\
\text { No. }\end{array}$} & \multirow[t]{2}{*}{ Characteristics } & \multicolumn{3}{|c|}{ Size of farm group } & \multirow{2}{*}{$\begin{array}{l}\text { Total } \\
\text { number of } \\
\text { samples }\end{array}$} \\
\hline & & small & medium & large & \\
\hline & $\begin{array}{l}\text { Size of farm groups } \\
\text { (in numbers) }\end{array}$ & $\begin{array}{l}26 \\
(100)\end{array}$ & $\begin{array}{l}8 \\
(100)\end{array}$ & $\begin{array}{l}4 \\
(100)\end{array}$ & $\begin{array}{l}38 \\
(100)\end{array}$ \\
\hline 1. & Maintain contact & $\begin{array}{l}18 \\
(70.84)\end{array}$ & $\begin{array}{l}5 \\
(61.53)\end{array}$ & $\begin{array}{l}3 \\
(60.00)\end{array}$ & $\begin{array}{l}26 \\
(68.42)\end{array}$ \\
\hline 2. & Do not maintain contact & $\begin{array}{l}8 \\
(29.16)\end{array}$ & $\begin{array}{l}3 \\
(38.46)\end{array}$ & $\begin{array}{l}1 \\
(40.00)\end{array}$ & $\begin{array}{l}12 \\
(31.57)\end{array}$ \\
\hline
\end{tabular}

Note: Figures in the parenthesis indicates percentage to the total size of farms group

Distribution of Bengalgram farmers according to their farming experience

From the Table 11,it was found that more than half of farmers $(57.44 \%)$ had medium bengalgram growing experience (8-28 years), followed by more and less bengalgram growing experience i.e., 23.42 per cent $(>28$ years $)$ and 19.17 per cent $(<8$ years $)$, respectively.

To enable them to effectively utilise their farm experience, the scientists and extension agencies have to conduct extension activities like trainings, result demonstrations, method demonstrations, meetings, exposure visits and group discussions so as to provide wide exposure to farmers and facilitate them to act further. The results were in conformity with that of Roy (2013), Yishak (2017), Neethi and Sailaja, (2014).

\section{Distribution of Greengram farmers according to their farming experience}

From the Table 12, it was found that more than half of farmers $(65.78 \%)$ had medium greengram growing experience (8-28 years), followed by more and less greengram growing experience i.e., 18.42 per cent $(>28$ years $)$ and 15.78 per cent $(<8$ years $)$, respectively. The results were in conformity with that of Roy (2013), Yishak (2017), Neethi and Sailaja (2014).

\section{Distribution of Redgram farmers} according to their annual Income

The Table 13, revealed that considerable per cent (63.34\%) of the Redgram farmers were in the range of middle annual income group (Rs. 302593-Rs.1420354/-) followed by 21.66 per cent in the low income category $(<$ Rs. $302593 /-)$ and 15.00 per cent in the high income category (Rs.>1420354/-) These findings are supported by the findings of Kamalakanth (2008), Neethi and Sailaja (2014).

As majority respondents had medium annual income. It was due to small farm size, medium innovativeness, medium economic orientation, medium market orientation, medium change proneness medium achievement motivation and medium information seeking behaviour as indicated in the study

\section{Distribution of Bengalgram farmers according to their annual Income}

The Table 14, revealed that considerable per cent $(61.76 \%)$ of the bengalgram farmers were in the range of middle annual income 
group (Rs. 302593-Rs.1420354/-) followed by 21.27 per cent in the low income category (<Rs. 302593/-) and 17.06 per cent in the high income category (Rs.>1420354/-) These findings are supported by the findings of Kamalakanth (2008), Neethi and Sailaja, (2014).

\section{Distribution of greengram farmers according to their annual Income}

The Table 15, revealed that considerable per cent $(63.15 \%)$ of the greengram farmers were in the range of middle annual income group (Rs. 302593-Rs.1420354/-) followed by 21.08 per cent in the low income category $(<\mathrm{Rs}$. 302593/-) and 15.78 per cent in the high income category (Rs.>1420354/-) These findings are supported by the findings of Kamalakanth (2008), Neethi, B. and Sailaja, A., (2014).

Distribution of Redgram farmers according to their Contact with Extension Agency

A good agricultural extension system was required to enhance the efficiency of farmers. Extension serves as a key linkage in the process of transferring technology from lab to land. For improving productivity the contacts between farmers and extension network is crucial.

From the Table 16, it is observed that the average of the farmers contact with extension agency was found to be $68.34 \%$ were as $31.66 \%$ of the farmers were not maintaining any contact with extension agency. Thus, there is still need to create awareness about the benefits of having contacts with extension agency to those who were not having any contact.

The same result was generated by (Samarpitha et al., 2016).
Distribution of Bengalgram farmers according to their Contact with Extension Agency

From the Table 17, it is observed that the average of the Bengalgram farmers contact with extension agency was found to be $65.95 \%$ were as $34.04 \%$ of the farmers were not maintaining any contact with extension agency. Thus, there is still need to create awareness about the benefits of having contacts with extension agency to those who were not having any contact. The same result was generated by Samarpitha et al., (2016).

\section{Distribution of Greengram farmers according to their Contact with Extension Agency}

From the Table 18, it is observed that the average of the Greengram farmers contact with extension agency was found to be $68.42 \%$ were as $31.57 \%$ of the farmers were not maintaining any contact with extension agency. Thus, there is still need to create awareness about the benefits of having contacts with extension agency to those who were not having any contact. The same result was generated by (Samarpitha et al., 2016).

In conclusion, pulses production is an important business to various farmers and this is highly demanding crop at national and international level which helps to increase the socio-economic condition of the farmers. Most of the pulses farmers in the study area were literates, belonged to medium family size. It was found that considerable pulses farmers had agriculture as main occupation.

Maximum of them belonged to middle age, having small size of land holding, medium farming experience and medium annual income and majority of the farmers were found to have contact with extension agencies which is crucial for improving productivity. 


\section{Application of research}

Main aim of the research area knows the socio-economic data of the farmers those who are growing the major pulses in Mahabubnagar district of Telangana state.

\section{Research Category}

Agriculture economics and Agri business.

\section{Acknowledgement / Funding}

Author thankful to Sam Higginbottom University of Agriculture, Technology and Sciences, Allahabad, Uttar Pradesh, 211007, India.

\section{References}

Abdulkadir K.O (2015) "An evaluation of the efficiency of onion producing farmers in irrigated agriculture: Empirical evidence from Kobo district, Amhara region, Ethiopia". International Scholars Journals, 2 (5), 116-124.

Annual Report 2017-18, www.agricoop.nic.in Annual Report DPD 2016-17.

Dhamodaran, T. and Vasantha Kumar, J. (2001) "Relationship between selected characteristics of registered sugarcane growers and their extent of adoption of improved sugarcane cultivation practices". Journal of. Extension. Education, 12(2), 3138-3143.

Jamanal S.K., and Sadaqath S. (2017) "Socioeconomic characteristics of soybean growers". Journal of Pharmacognosy and Phytochemistry, 6(5), 2766-2768.

Kamalakanth, (2008) "A critical analysis of knowledge level and adoption behavior of wheat growers in Bidar district of north Karnataka". M.Sc. (Agri) Thesis (Unpub), University of Agricultural Sciences, Bangalore.

Kanade Amol Uttam (2017) Resource use efficiency and price behaviour of Greengram in Marathwada region of Maharashtra Ph.D Thesis submitted to the Vasantrao Naik Marathwada Krishi Vidyapeeth, Parbhani Maharashtra.

Neethi B. and Sailaja A. (2014) Study of Socio-Economic Profile of Farmers in Mahabubnagar District of Andhra Pradesh. Global Journal for Research Analysis, 3(8), $2277-8160$.

Roy, M.L., Chandra, N., Kharbikar, H.L., Joshi, P. and Jethi, R. (2013) "Socioeconomic Status of Hill Farmers: An Exploration from Almora District in Uttarakhand". International Journal of Agriculture and Food Science Technology, 4(2), 353-358.

Samarpitha A., Vasudev N., Suhasini K. (2016) "Socio-economic Characteristics of Rice Farmers in the Combined State of Andhra Pradesh". Asian Journal of Agricultural Extension,

Yishak G. (2017) "Rural Farm Households' Income Diversification: The Case of Wolaita Zone, Southern Ethiopia". Social Sciences, 6(2), 45-56.

\section{How to cite this article:}

Vinaya Kumari M., Amit Kumar Masih, Nahar Singh, Ashish Samarpit Noel and Kumud Shukla. 2019. Study of Socio - Economic Profile of the Selected Pulses Growing Farmers in Mahabubnagar District of Telangana State. Int.J.Curr.Microbiol.App.Sci. 8(07): 3041-3055. doi: https://doi.org/10.20546/ijcmas.2019.806.363 